\title{
IMPLEMENTASI PENDIDIKAN KARAKTER DALAM PEMBELAJARAN SAINS
}

\author{
Rifda Mardian Arif \\ Stkip PGRI Banjarmasin \\ Email: dianrifda@stkipbjm.ac.id
}

\begin{abstract}
Abstrak
Krisis multidimensi yang telah melanda bangsa Indonesia yang kemudian "diobati" dengan reformasi, ternyata diikuti pula oleh beberapa penyimpangan yang bersifat kontraproduktif, yakni krisis etika dan moralitas yang semakin akut. Pendidik yang handal, profesional dan berdaya saing tinggi, serta memiliki karakter yang kuat dan cerdas merupakan modal dasar dalam mewujudkan pendidikan yang berkualitas yang mampu mencetak sumberdaya manusia yang berkarakter, cerdas dan bermoral tinggi. Karakter yang dapat diterapkan melalui pembelajaran Ilmu Pengetahuan Alam (SAINS) adalah objektif (objectivity), teliti (accuracy), tepat (precisión), mencari kebenaran (pursuit of truth), pemecahan masalah (problem solving), keselamatan dan resiko (protect human file: safety and risk), manusiawi (regard human significance), kejujuran intelektual (intelectual honesty), kejujuran akademik (academic honesty), berani (courage), rendah hati (humility), pengambilan keputusan (decisión-making), kesediaan menunda keputusan (willingness to suspend judgment), inkuiri sains (scientific inquirí: being fair and just), bertanya tentang semua hal (questioning of all thing), memverifikasi (demand for verification), menjunjung tinggi logika (respect fo logic), integritas (integrity), tekun/gigih (diligence), ulet (persistence), ingin tahu (curiosity), berpikiran terbuka (open-mindedness), evaluasi alternatif secara kritis (critical evaluation of alternatives) dan imaginasi (imagination). Belum maksimalnya pendidikan karakter yang dilaksanakan selama ini karena masih menggunakan cara berikut: 1) pendidikan karakter tidak dirancang dalam pembelajaran. 2) pendidikan karakter hanya masuk pada kegiatan ekstra. 3) dan pendidikan karakter menjadi pelajaran tersendiri. Beberapa pendekatan ideal yang dapat dilakukan terkait dengan pendidikan karakter adalah: 1) pendekatan holistik, 2) membangun sebuah "Komunitas Peduli", 3) mengajarkan nilai-nilai melalui kurikulum, 4) diskusi kelas, 5) dan layanan belajar (learning service). Melalui pembelajaran dengan metode praktikum di samping melatihkan kecakapan intelektual dan keterampilan siswa (berpikir ilmiah dan proses ilmiah) dapat dilatihkan pula sikap ilmiah yang komponen-komponennya meliputi: ketelitian, kejujuran, tanggung jawab, kebersamaan, etika, dll yang akan membentuk karakter siswa jika pembiasaan tersebut telah melekat pada diri siswa. Pendidikan karakter yang merupakan tanggung jawab bersama perlu dilakukan melalui strategi pengembangan secara mikro bagi dunia pendidikan (sekolah), namun juga perlu dilakukan melalui strategi dalam konteks makro (nasional), agar pendidikan karakter menjadi habitual bukan sekedar wacana.
\end{abstract}

Kata Kunci: Dekadensi moral, pendidikan karakter, pembelajaran SAINS , holistik 


\section{PENDAHULUAN}

Bapak Pendidikan Nasional Ki hadjar Dewantara mengatakan bahwa pendidikan merupakan daya upaya memajukan pertumbuhan budi pekerti (kekuatan batin, karakter), pikiran (intelect) dan tubuh anak, dimana bagianbagian tersebut tidak boleh dipisahkan agar kita dapat memajukan kesempurnaan hidup anak-anak kita. Pendidikan dalam arti luas adalah proses yang berkaitan dengan upaya untuk mengembangkan pada diri seseorang tiga aspek dalam kehidupannya, yakni, pandangan hidup, sikap hidup dan keterampilan hidup. Upaya untuk mengembangkan ketiga aspek tersebut bisa dilaksanakan di sekolah, luar sekolah dan keluarga. Dengan mendasarkan pada konsep pendidikan tersebut di atas, sesungguhnya pendidikan merupakan pembudayaan atau "enculturation", yaitu suatu proses untuk mentasbihkan seseorang mampu hidup dalam suatu budaya tertentu. Konsekuensi dari pemyataan ini, praktek pendidikan harus sesuai dengan budaya masyarakat. Jika praktek pendidikan menyimpang dari budaya yang ada dimasyarakat, maka akan menimbulkan goncangan-goncangan kehidupan individu dan masyarakat.

Krisis multidimensi yang telah melanda bangsa Indonesia yang kemudian “diobati” dengan reformasi, ternyata diikuti pula oleh beberapa penyimpangan yang bersifat kontraproduktif, yakni krisis etika dan moralitas yang semakin akut. Dekadensi moral yang luar biasa merupakan penyebab utama keterpurukan bangsa yang dulu dikenal sebagai bangsa yang santun dan taat beragama. Indonesia sebagai bangsa dengan penduduk muslim terbesar di dunia dan melandaskan falsafah negaranya pada Ketuhanan Yang Maha Esa, ternyata menjadi negara yang paling korup di Asia dan di dunia. Angka Human Development Index (HDI) kita juga tertinggal jauh dengan negara yang dulunya belajar dari kita. Prestasi yang semakin menurun dan citra yang buruk merupakan ironi bagi kita. Perubahan bangsa baik yang mengarah kepada kemajuan (progresif) maupun yang mengarah kepada kemunduran (regresif) merupakan masalah yang terkait langsung maupun tidak langsung dengan penyelengaraan pendidikan, baik formal, maupun informal.

Untuk menjawab pertanyaan "what is science?", dalam buku yang berjudul 'UNESCO Handbook for Science Teachers' yang diterbitkan oleh UNESCO Paris dijelaskan bahwa "Science is what scientists do", maksudnya, 
pertama adalah mengumpulkan pengetahuan ilmiah sehingga menjadi 'body of scientific knowledge' dan yang kedua adalah suatu proses untuk mendapatkan 'scientific knowledge' itu. Pembelajaran Ilmu Pengetahuan Alam (IPA) sebenarnya tidak terlepas dengan pengembangan karakter karena dalam pembelajaran Ilmu Pengetahuan Alam (IPA) tidak terlepas dari objektivitas (objectivity), ketelitian (accuracy), ketepata (precisión), mencari kebenaran (pursuit of truth), pemecahan masalah (problem solving) dsb.

Dari berbagai pengamatan selama ini terdapat siswa dan guru yang berkarakter kurang baik, meskipun belum diketahui pasti berapa banyak siswa dan guru yang berkarakter kurang baik tersebut, namun perlu diupayakan untuk ditekan seminimal mungkin. Di samping itu, guru sebagai pemeran kunci dalam pembelajaran di sekolah diduga belum berperan maksimal dalam pembentukan karakter siswa.

Urgensi dari pelaksanaan komitmen nasional pendidikan karakter, telah dinyatakan pada Sarasehan Nasional Pendidikan Budaya dan Karakter Bangsa sebagai kesepakatan nasional pengembangan pendidikan budaya dan karakter bangsa yang dibacakan pada akhir-akhir sarasehan tanggal 14 Januari 2010, sebagai berikut.

1. Pendidikan budaya dan karakter bangsa merupakan bagian integral yang tak terpisahkan dari pendidikan nasional secara utuh

2. Pendidikan budaya dan karakter bangsa harus dikembangkan secara komprehensif sebagai proses pembudayaan.Oleh karena itu pendidikan dan kebudayaan secara kelembagaan perlu diwadahi secara utuh

3. Pendidikan budaya dan karakter bangsa merupakan tanggung jawab bersama antara pemerintah, masyarakat, sekolah dan orang tua. Oleh karena itu pelaksanan budaya dan karakter bangsa harus melibatkan keempat unsur tersebut

4. Dalam upaya merevitalisasi pendidikan budaya dan karakter bangsa diperlukan gerakan nasional guna menggugah semangat kebersamaan dalam pelaksanaan di lapangan 


\section{KONSEP ESSENSIAL PENDIDIKAN KARAKTER}

Istilah nation and charakter building adalah istilah klasik dan menjadi kosa kata hampir sepanjang sejarah modern Indonesia terutama sejak peristiwa Sumpah Pemuda 1928. Istilah ini mencuat kembali sejak tahun 2010 ketika pendidikan karakter dijadikan sebagai gerakan nasional pada puncak acara Hari Pendidikan Nasional 20 Mei 2010 yang dicanangkan oleh presiden RI1. Latar belakangmunculnya pendidikan karakter ini dilatarbelakangi oleh semakin terkikisnya karakter sebagai bangsa Indonesia, dan sekaligus sebagai upaya pembangunan manusia Indonesia yang berakhlak budi pekerti yang mulia.

Istilah karakter secara harfiah berasal dari bahasa Latin "Charakter", yang antara lain berarti: watak, tabiat, sifat-sifat kejiwaan, budi pekerti, kepribadian atau akhlak. Sedangkan secara istilah, karakter diartikan sebagai sifat manusia pada umumnya dimana manusia mempunyai banyak sifat yang tergantung dari faktor kehidupannya sendiri.2 Karakter adalah sifat kejiwaan, akhlak atau budi pekerti yang menjadi ciri khas seseorang atau sekelompok orang3. Definisi dari "The stamp of individually or group impressed by nature, education or habit. Karakter merupakan nilai-nilai perilaku manusia yang berhubungan dengan Tuhan Yang Maha Esa, diri sendiri, sesama manusia, lingkungan, dan kebangsaan yang terwujud dalam pikiran, sikap, perasaan, perkataan, dan perbuatan berdasarkan norma-norma agama, hukum, tata krama, budaya, dan adat istiadat.

\section{Hubungan Karakter dengan Ilmu Pengetahuan Alam}

Thomas Lickona (1991) mendefinisikan karakter adalah sifat alami sesorang dalam merespon situasi secara bermoral yang dimanifestasikan dalam tindakan nyata melalui tingkah laku yang baik, jujur, bertanggung jawab, menghormati orang lain dan karakter mulia lainnya. Pengertian ini mirip dengan apa yang diungkapkan oleh Aristoteles, bahwa karakter erat kaitannya dengan “habit” atau kebiasaan yang terus menerus dilakukan. Menurut Berkowitz (1998), kebiasaan berbuat baik tidak selalu menjamin bahwa manusia yang terbiasa baik tersebut secara sadar menghargai pentingnya nilai-nilai karakter (valuing). Misalnya seseorang yang terbiasa berkata jujur karena takut mendapatkan hukuman maka bisa saja orang ini tidak mengerti nilai moral dari kejujuran itu 
sendiri. Ini menunjukkan bahwa pendidikan karakter juga memerlukan juga aspek emosi. Lickona (1991), menyatakan komponen ini disebut "desiring the good" atau berkeinginan untuk berbuat baik. Berdasarkan beberapa definsi di atas maka karakter merupakan potensi nilai yang dimiliki seseorang yang diwujudkan dalam kehidupan sehari-hari.

Menurut pendapat dari Nash, L.K. dalam bukunya 'The Nature of Natural Science'. Ia mengatakan bahwa IPA itu dipandang sebagai suatu cara atau metode untuk dapat mengamati sesuatu, dalam hal ini adalah dunia. Cara memandang IPA bersifat analitis, ia melihat sesuatu secara lengkap dan cermat serta dihubungkannya dengan objek yang diamati itu. IPA dipandang sebagai suatu pola pikir logis dan seragam. Lalu apa dan bagaimana pola pikir logis dan seragam itu yang tak lain adalah metode ilmiah. Sebuah buku karangan J.D. Bernal yang berjudul 'Science in History'. Di dalam isi buku tersebut, Bernal menyarankan untuk dapat memahami sains atau IPA haruslah melalui pemahaman dari berbagai segi atau aspek dari IPA itu. Ia menonjolkan adanya lima aspek yaitu IPA dapat dipandang: sebagai suatu institusi, sebagai suatu metode, sebagai suatu kumpulan pengetahuan, sebagai suatu faktor utama dalam memelihara dan mengembangkan produksi, sebagai salah satu faktor utama yang mempengaruhi kepercayaan dan sikap manusia terhadap alam semesta. Sidney Morgenbesser dalam buku yang berjudul 'Philosophy of Science Today' membahas tentang 'The Nature and Aims of Science' yang dikarang oleh Ernest Nagel.

Pembelajaran Ilmu Pengetahuan Alam (IPA) sebenarnya tidak terlepas dengan pengembangan karakter. Karakter yang dapat dikembangkan melalui pembelajaran Ilmu Pengetahuan Alam (IPA) adalah objektif (objectivity), teliti (accuracy), tepat (precisión), mencari kebenaran (pursuit of truth), pemecahan masalah (problem solving), keselamatan dan resiko (protect human file: safety and risk), manusiawi (regard human significance), kejujuran intelektual (intelectual honesty), kejujuran akademik (academic honesty), berani (courage), rendah hati (humility), pengambilan keputusan (decisión-making), kesediaan menunda keputusan (willingness to suspend judgment), inkuiri sains (scientific inquirí: being fair and just), bertanya tentang semua hal (questioning of all thing), memverifikasi (demand for verification), menjunjung tinggi logika (respect fo 
logic), integritas (integrity), tekun/gigih (diligence), ulet (persistence), ingin tahu (curiosity), berpikiran terbuka (open-mindedness), evaluasi alternatif secara kritis (critical evaluation of alternatives) dan imaginasi (imagination)

Agar karakter tersebut terwujud pada diri seseorang maka diperlukan pembiasaan dalam kehidupan sehari-hari, baik melalui pendidikan di rumah maupun pendidikan sekolah, yang disebut dengan pendidikan karakter. Pendidikan karakter menurut Thoman Lickona adalah usaha secara sengaja untuk membantu memahami, peduli dan bertindak berdasarkan nilai-nilai etika inti. Dalam bukunya Educating for Children, Lickona menegaskan bahwa "ketika kita berpikir tentang jenis karakter yang kita inginkan bagi anak-anak kita, jelas bahwa kita ingin mereka bisa menilai apa yang benar, perhatian secara mendalam tentang apa yang benar, dan kemudian melakukan apa yang mereka yakini untuk menjadi benar - bahkan dalam menghadapi tekanan dari luar dan godaan dari dalam." Secara sederhana pendidikan karakter adalah segala sesuatu yang kita lakukan secara sengaja yang mempengaruhi karakter anak-anak yang kita ajar.

\section{PENDIDIKAN KARAKTER DALAM PEMBELAJARAN SAINS}

Kapan pembelajaran IPA (SAINS) dapat diaplikasikan untuk membentuk karakter siswa? Dapat dinalisis berdasarkan karakter apa yang akan dikembangkan.

\section{Karakter dalam hubungannya dengan Tuhan Yang Maha Kuasa (Religius) : Bertaqwa pada Tuhan Yang Maha Kuasa}

Apakah pengembangan ketaqwaan siswa melalui kegiatan pembelajaran untuk setiap mata pelajaran di sekolah penting?

Persoalannya adalah, Apakah selama ini:

1. Buku-buku pelajaran sains (IPA) yang dipakai di sekolah saat ini ada yang mengkaitkan materi pelajaran IPA dengan aspek keimanan dan ketaqwaan? Tampaknya belum semuanya bisa.

2. Apakah dalam pembelajaran IPA selama ini para guru IPA bisa mengkaitkan pelajaran IPA dengan aspek keimanan dan ketaqwaan? Tampaknya belum semuanya bisa.

3. Apakah selama ini guru sain mau mengkaitkan materi pelajaran IPA 
dengan aspek keimanan dan ketaqwaan? Tampaknya belum semuanya mau.

4. Seriuskah kemdiknas melaksanakan amanat yang tertuang dalam pendahuluan Kurikulum K13 serta Fungsi dan tujuan dalam Kurikulum K13? Tampaknya belum serius.

Jadi, apa yang diperoleh dari hasil pembelajaran IPA di sekolah? Tampaknya hanyalah:
a. Pengetahuan tentang IPA.
b. Sedikit keterampilan laboratorium.

Kapan pembelajaran IPA (SAINS) dapat digunakan sebagai alat untuk meningkatkan keimanan dan ketaqwaan kepada Tuhan Yang Maha Esa? Apabila kegiatan pembelajaran dapat menumbuhkan kesadaran bahwa:

(1) ilmu yang kita miliki atau pahami itu amat sedikit.

(2) kita betul-betul sangat tergantung pada rahmat dan belas kasihan dari Tuhan Yang Maha Esa.

(3) ketentuan yang ditetapkan oleh Tuhan Yang Maha Esa adalah yang terbaik bagi kita.

(4) larangan-larangan yang ditetapkan oleh Tuhan Yang Maha Esa betul-betul bermanfaat bagi kita.

(5) adanya keteraturan pada alam semesta.

(6) perintah-perintah yang ditetapkan oleh Tuhan Yang Maha Esa betul-betul bermanfaat bagi kita.

(1) Kesadaran akan amat sedikitnya ilmu yang kita pahami atau ketahui

Bagaimana kita tahu bahwa ilmu yang kita pahami atau ketahui itu amat sedikit? Misalnya dalam bidang ilmu kimia. Apa indikator perkembangan ilmu kimia? Jumlah senyawa kimia yang berhasil disintesis oleh semua peneliti kimia di seluruh dunia pertahun. Berapa jumlahnya? Sekitar 30 ribu pertahun, dan jumlah ini cenderung semakin meningkat. Abstrak (ringkasan) hasil penelitian dalam bidang ilmu kimia dan bidang-bidang lain yang berkaitan. Berapa banyak? Tidak kurang dari 1000 halaman setiap minggu.

(2) Kesadaran bahwa kita betul-betul sangat tergantung pada rahmat dan belas kasihan dari Tuhan Yang Maha Esa

Bagaimana kita merasa sangat tergantung pada rahmat dan belas kasihan 
dari Tuhan Yang Maha Esa? Apa contohnya? Pemahaman tentang air yang kita minum. Sebagian besar dari kita mungkin telah mengetahui bahwa molekulmolekul air dapat mengadakan ikatan hidrogen antarmolekul. Pada air cair molekul-molekul membentuk ikatan hidrogen antarmolekul seperti ditunjukkan pada gambar berikut:

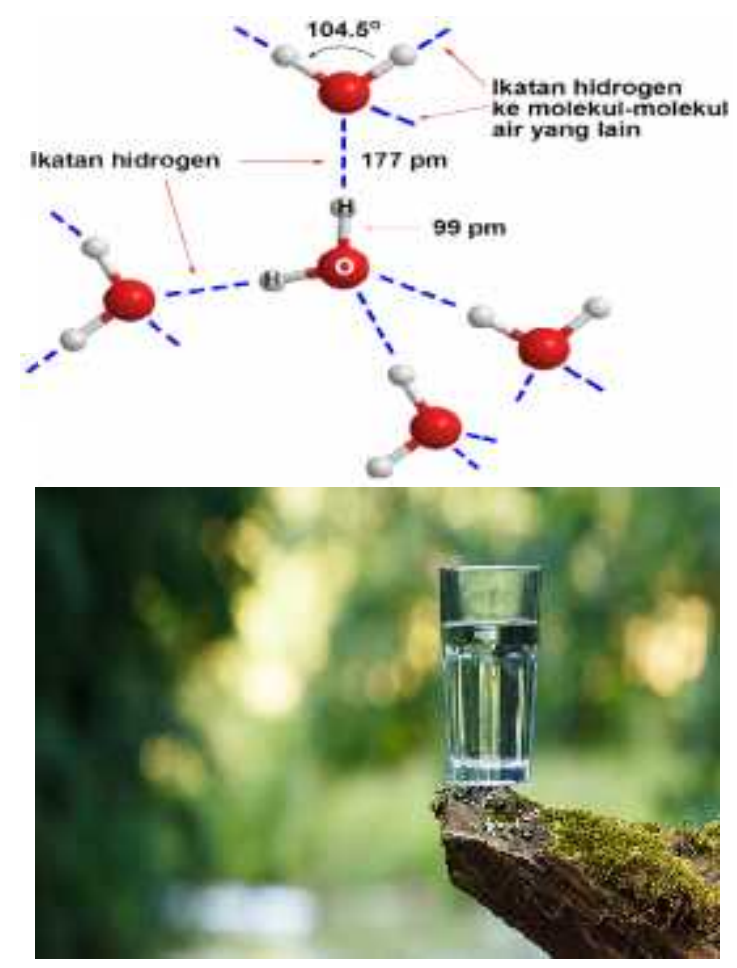

Apa pengaruh ikatan hidrogen tersebut? Pada suhu ruang air masih dalam fase cair. Bagaimana kalau antara molekul-molekul air tidak terjadi ikatan hidrogen antarmolekul? Pada suhu sekitar $-100{ }^{\circ} \mathrm{C}$ air sudah mendidih, sehingga tidak akan ada organisme yang dapat hidup di bumi.

Apa yang terjadi seandainya semua tumbuh-tumbuhan mogok kerja dan tidak mau menghasilkan karbohidrat yang dibutuhkan oleh manusia dan hewan? Misalnya: padi mogok berbuah. Untuk mendapatkan sepiring nasi, nasi itu terpaksa harus disintesis di laboratorium. Sudah bisakah nasi disintesis di laboratorium? BELUM BISA, Seandainya bisa kira-kira berapa biayanya?Sintesis satu piring nasi akan memerlukan biaya ratusan juta rupiah. 


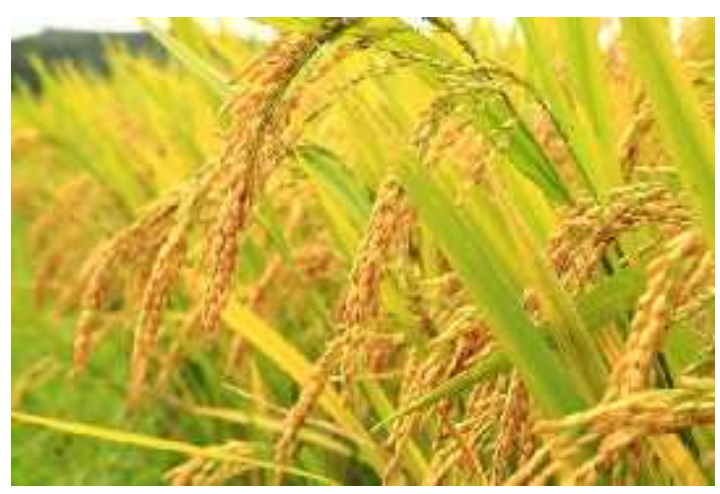

(3) Kesadaran bahwa bahwa yang ditetapkan oleh Tuhan Yang Maha Esa adalah yang terbaik bagi kita semua.

Bagaimana seandainya kelebihan energi dalam tubuh disimpan sebagai karbohidrat? Kita harus tahu kesetaraan energi dari lemak dan karbohidrat. Energi yang dihasilkan oleh 1 gram lemak $=2,2727 \mathrm{x}$ energi yang dihasilkan oleh 1 gram karbohidrat. Apa yang terjadi bila kelebihan energi disimpan sebagai karbohidrat? Penambahan berat badan kita menjadi 2,2727 kali. Misalnya: Seorang ibu dengan berat badan normal $45 \mathrm{~kg}$. Karena makan berlebihan beratnya menjadi $60 \mathrm{~kg}$, dengan kelebihan energi disimpan sebagai lemak. Berapa beratnya bila kelebihan energi tersebut disimpan sebagai karbohidrat? Berat ibu tersebut menjadi $79 \mathrm{~kg}$. Apa yang terjadi dengan burung bila kelebihan energi disimpan sebagai karbohidrat? Burung-burung tidak bisa terbang.

(4) Kesadaran bahwa larangan-larangan yang ditetapkan oleh Tuhan Yang Maha Esa betul-betul bermanfaat bagi kita

Apa contoh larangan? Larangan minum minuman keras. Mengapa dilarang?

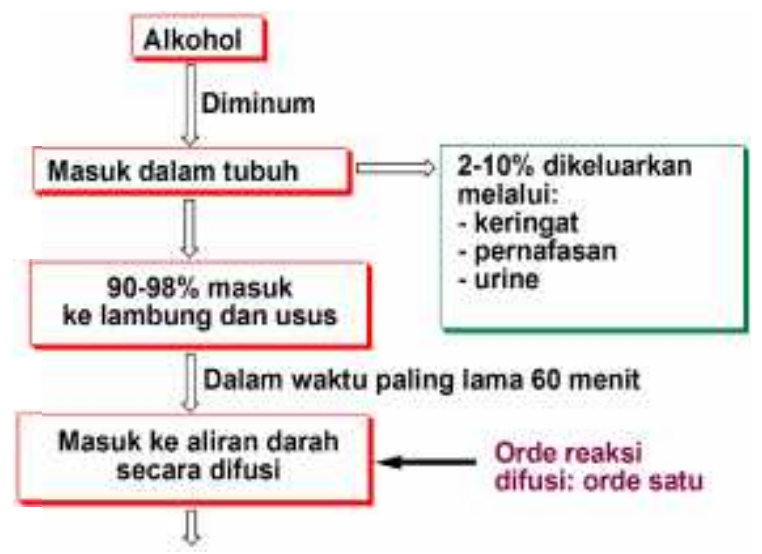


Stilistika: Jurnal Bahasa, Sastra, dan Pengajarannya

ISSN 2527-4104

Vol. 2 No.1, 1 April 2017

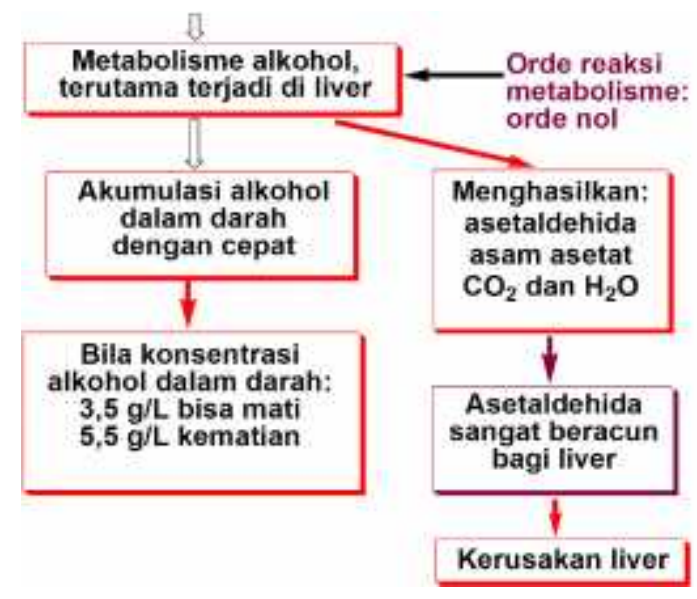

(5) Adanya keteraturan pada alam semesta

Apa contohnya? Keteraturan dari peredaran bumi dalam mengedari matahari sehingga malam dan siang terjadi secara silih berganti.
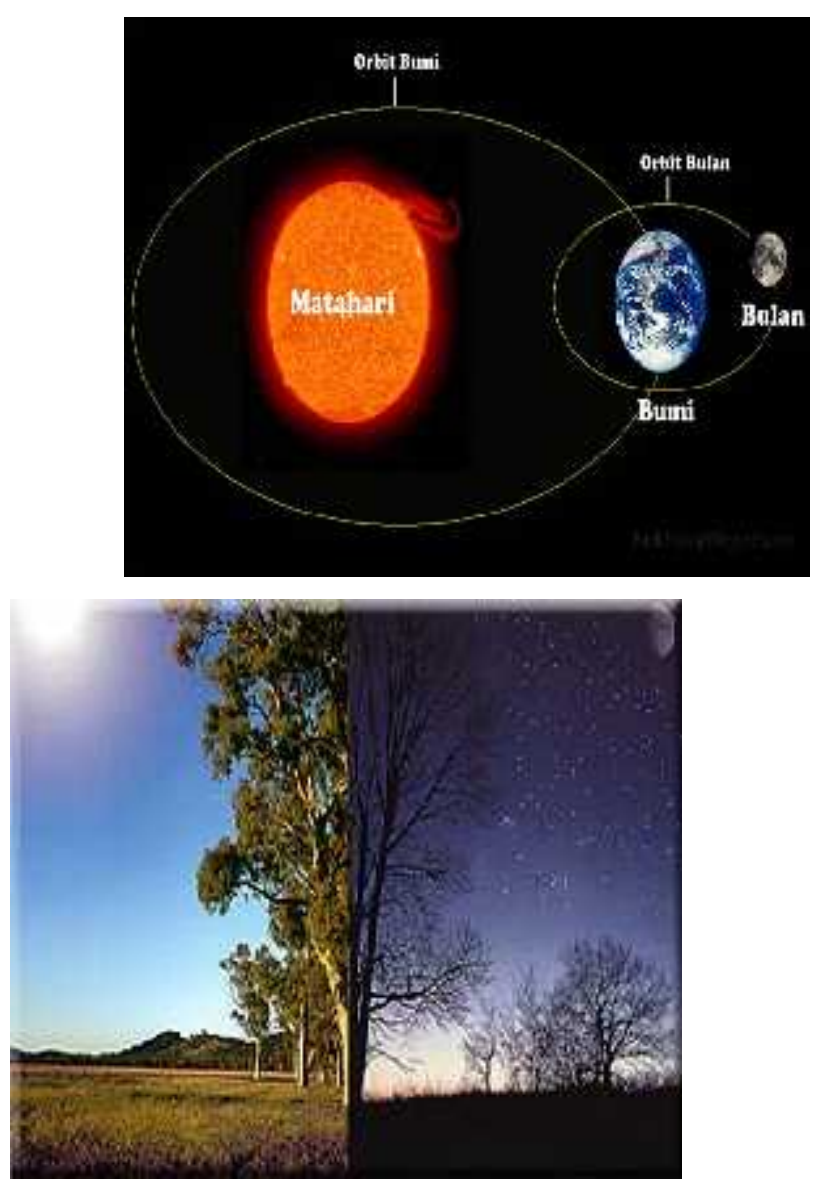

Bumi mengelilingi matahari

Terjadinya siang dan malam

(6) Apabila kita menyadari bahwa perintah-perintah yang ditetapkan oleh 
Tuhan Yang Maha Esa bermanfaat bagi kita

Apa contoh perintah? Perintah untuk makan makanan yang baik dan bergizi.

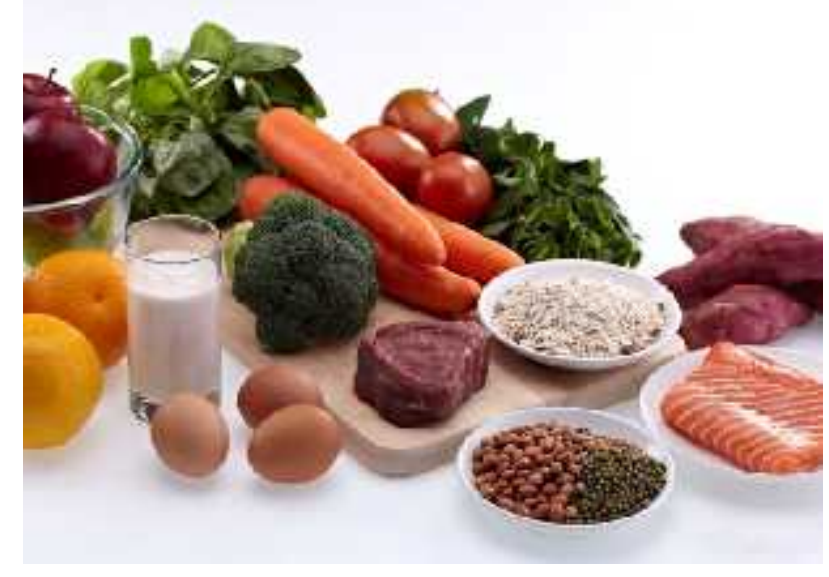

\section{Karakter dalam hubungannya dengan diri sendiri}

Antara lain: (1) Jujur, (2) Tanggung jawab, (3) Disiplin, (4) Kerja keras, (5) Percaya diri, (6) Berfikir logis, kritis, kreatif, inovatif dan (7) Cinta ilmu. Cenderung lebih mudah dibentuk apabila pembelajaran IPA menggunakan pendekatan yang berpusat pada siswa (student centered) dibandingkan berpusat pada guru (teacher centered). Beberapa pendekatan pembelajaran yang relatif sangat efektif untuk mengembangkan karakter-karakter di atas adalah (a) Inquiry, (b) Problem solving, (c) Learning cycle

\section{Karakter dalam hubungannya dengan sesama}

Antara lain: (1) Menghargai karya dan prestasi orang lain, (2) Santun, (3) Demokratis

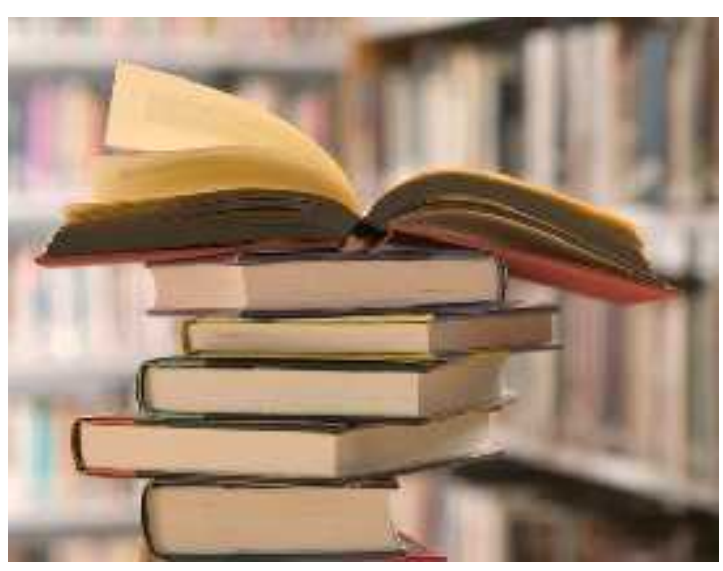




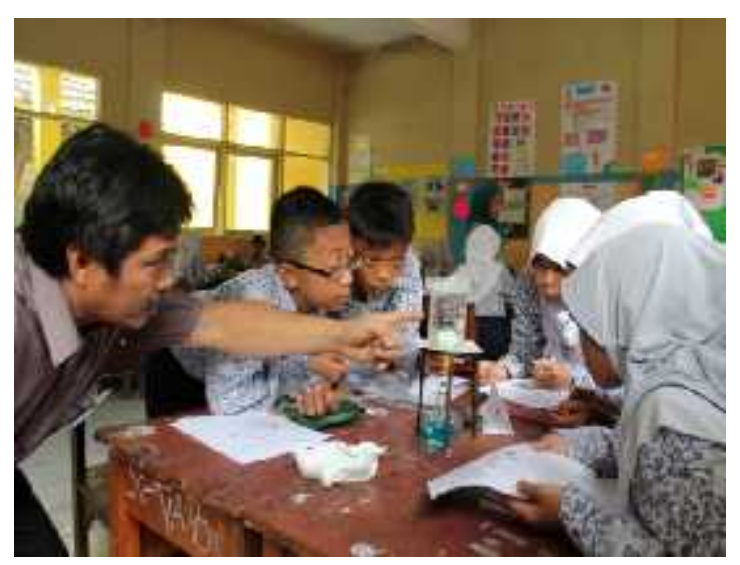

Karakter menghargai karya dan prestasi Demokratis orang lain. Contoh dalam pembuatan karya ilmiah
Karakter Santun dan

menggunakan pendekatan "cooperative learning".

\section{Karakter dalam hubungan dengan lingkungan}

Antara lain: (1) Peduli sosial dan (2) Peduli lingkungan. Pembelajaran IPA dilakukan secara terpadu, baik secara connected, integrated maupun bentukbentuk keterpaduan yang lain. Pembelajaran biologi, fisika, dan kimia selalu dikaitkan dengan masalah lingkungan.

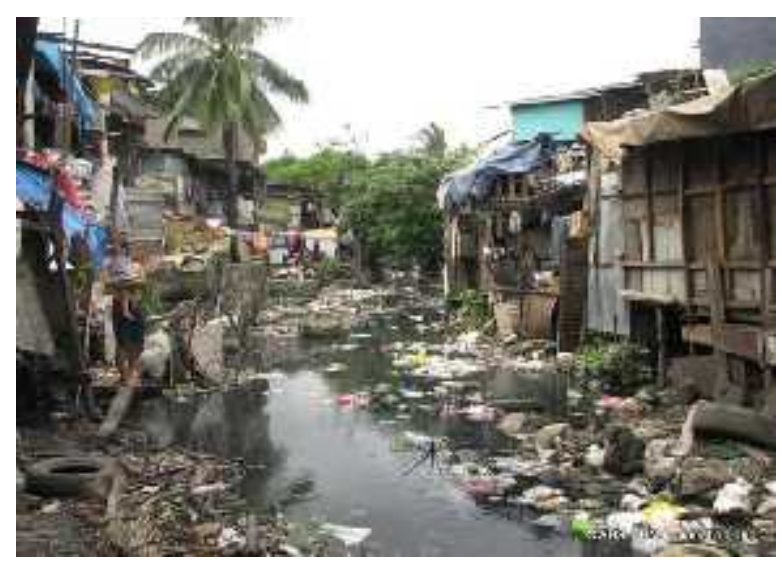

Contoh pencemaran lingkungan yang dikaitkan dengan masalah banjir beserta dampaknya bagi kesehatan

\section{Karakter berkaitan dengan kebangsaan}

Antara lain: (1) Nasionalis dan (2) Menghargai keberagaman. Karakter nasionalis dapat dikembangkan apabila pada siswa tertanam kesadaran bahwa nilai hidup tidak boleh didasarkan pada finansial semata tetapi pada manfaat yang dapat diberikan pada lingkungan yang ada. Contohnya banyak mahasiswa Indonesia yang kuliah di luar negeri, kemudian mendapatkan pekerjaan yang lebih 
memenuhi dari segi finansial dan pengembangan karir di luar negeri

\section{Pendekatan Ideal Pendidikan Karakter}

Berdasarkan uraian di atas, tampak kelemahan implementasi pendidikan karákter yang telah dilakukan selama ini sehingga perlu dipikirkan pendekatan bagaimana agar pendidikan karakter dapat lebih berhasil. Beberapa pendekatan ideal yang dapat dilakukan terkait dengan pendidikan karakter dapat diuraikan sebagai berikut :

1. Pendekatan holistik

Pendidikan karakter tidak menambahkan program atau seperangkat program ke sekolah. Justru itu adalah transformasi budaya dan kehidupan sekolah. Kebijakan umum berpendapat bahwa cara terbaik untuk menerapkan pendidikan karakter adalah melalui pendekatan holistik yang mengintegrasikan pembangunan karakter ke dalam setiap aspek kehidupan sekolah. Pendekatan ini juga dikenal sebagai sekolah reformasi menyeluruh, dan itu adalah masalah yang sangat penting. Beberapa fitur yang menggambarkan model holistik:

a. Segala sesuatu di sekolah disusun berdasarkan hubungan antara dan di kalangan siswa, guru, staf, dan masyarakat.

b. Sekolah adalah komunitas siswa peduli di mana ada ikatan yang menghubungkan siswa, guru, staf, dan sekolah.

c. Sosial dan emosional ditekankan dalam pembelajaran.

d. Kerjasama dan kolaborasi antar siswa ditekankan dari pada persaingan.

e. Nilai-nilai seperti keadilan, menghormati, dan kejujuran adalah bagian dari pelajaran sehari-hari dalam dan keluar dari kelas.

f. Siswa diberi kesempatan yang luas untuk mempraktekkan perilaku moral melalui berbagai kegiatan seperti layanan belajar.

g. Disiplin dan pengelolaan kelas berkonsentrasi pada pemecahan masalah daripada imbalan dan hukuman.

h. Model lama pembelajaran berpusat pada guru dikelas ditinggalkan dan diganti menjadi kelas demokratis yang mana guru dan siswa di kelas 
mengadakan pertemuan untuk membangun kesatuan, menetapkan normanorma, dan memecahkan masalah.

2. Membangun sebuah" Komunitas Peduli"

Dengan "komunitas peduli" berarti bahwa semua orang di sekolah yaitu siswa, guru, dan staf memperlakukan orang lain dengan kebaikan dan rasa hormat. Untuk mencapai tujuan mulia tersebut, siswa perlu memainkan peran aktif dalam membentuk budaya dan lingkungan kelas, maupun sekolah pada umumnya. Beberapa cara untuk membuat hal itu terjadi adalah:

a. Mengadakan pertemuan kelas di mana siswa dalam kelompok menetapkan tujuan, menentukan aturan perilaku, merencanakan kegiatan-kegiatan, dan memecahkan masalah.

b. Meminta siswa berkolaborasi pada tugas-tugas akademik dengan bekerja dalam kelompok pembelajaran kooperatif. Memberi mereka kesempatan untuk merencanakan dan memikirkan cara-cara mereka bekerja bersamasama.

c. Mengatur sebuah program dimana siswa yang lebih muda dan tua berkumpul untuk bekerja menyatu pada tugas akademis dan jenis kegiatan lainnya.

d. mengajari resolusi konflik dan keterampilan sosial lainnya sehingga siswa menjadi terampil dalam menyelesaikan konflik secara adil dan damai.

Strategi-strategi ini membantu siswa belajar untuk membangun dan memelihara hubungan positif dengan orang lain. Mereka juga mengubah sekolah menjadi laboratorium tempat praktek siswa jenis-jenis peran, dan mengatasi jenis tantangan, yang akan mereka hadapi di kehidupan kemudian.

\section{Mengajarkan nilai-nilai melalui kurikulum}

Pelaksanaan kurikulum khususnya pembelajaran di kelas mempunyai peluang yang sangat besar dalam mengajarkan nilai-nilai kepada siswa. Misalnya kita akan mengajarkan materi tentang "sampah" pada siswa. Siswa akan ditanya apa yang kamu lakukan jika kelasmu kotor? Di mana kamu membuang sampah? Mengapa kamu melakukan hal itu? Apa manfaatnya bagi kehidupanmu? Dengan pertanyaan-pertanyaan seperti ini, nilai-nilai seperti disiplin, tanggungjawab, kerjasama akan terbangun pada diri siswa, sehingga 
akan membentuk karakter siswa yang suka hidup bersih.

\section{Diskusi Kelas}

Diskusi merupakan cara terbaik untuk menanamkan nilai-nilai yang dinginkan sehingga mampu membentuk karakter siswa yang baik. Dengan diskusi siswa mengembangkan nilai-nilai kejujuran, bijaksana, berpikir kritis, toleransi, menghargai teman, bekerjasama, tanggung jawab, dan refleksi.

5. Layanan Belajar (Learning service)

Layanan belajar adalah pendekatan pengajaran di mana tujuan-tujuan akademis dilakukan melalui pelayanan masyarakat. Dalam layanan belajar siswa akan membuat seleksi, perencanaan, dan kemudian merefleksikan seluruh pengalaman mereka. Selain konten akademik, para siswa juga praktek keterampilan praktis yang berharga seperti pengorganisasian, berkolaborasi, dan pemecahan masalah. Dengan layanan belajar ini siswa akan menngunakan karakter kebajikan, menunjukkan rasa hormat, mengambil tanggung jawab, empati, kerjasama, kewarganegaraan, dan ketekunan.

\section{KESIMPULAN}

Pendidik (guru) merupakan komponen vital dan fundamental dalam proses pendidikan, yang mengedepankan proses pematangan kejiwaan, pola pikir dan pembentukan serta pengembangan karakter (character building) bangsa untuk mewujudkan manusia Indonesia seutuhnya.

Belum maksimalnya pendidikan karakter yang dilaksanakan selama ini karena menggunakan cara berikut : 1) pendidikan karakter tidak dirancang dalam pembelajaran. 2) pendidikan karakter hanya masuk pada kegiatan ekstra. 3) dan pendidikan karakter menjadi pelajaran tersendiri.

Beberapa pendekatan ideal yang dapat dilakukan terkait dengan pendidikan karakter adalah: 1) pendekatan holistik, 2) membangun sebuah "Komunitas Peduli", 3) mengajarkan nilai-nilai melalui kurikulum, 4) diskusi kelas, 5) dan layanan belajar (learning service).

Pembelajaran dengan metode praktikum merupakan satu contoh peluang yang terbuka lebar untuk mengembangkan karakter siswa dalam pembelajaran, karena di samping melatihkan kecakapan intelektual dan keterampilan siswa 
(berpikir ilmiah dan proses ilmiah) dapat dilatihkan pula sikap ilmiah yang komponen-komponennya meliputi: ketelitian, kejujuran, tanggung jawab, kebersamaan, etika, dll yang akan membentuk karakter siswa jika pembiasaan tersebut telah melekat pada diri siswa.

\section{DAFTAR PUSTAKA}

Baedhowi dan Hartoyo (2005). Laporan 2005 Learning Round-table on Advanced Teacher Professionalism. Bangkok, Thailand 13 - 14 uni 2005

Csikszentmihalyi, M dan McCormack, J. The Influence of Teachers. Dalam Kevin Ryan dan James M. Cooper (Eds). (2004) Kaleidoscope: readings in Education. New York: Houghton Miffin Company

Davies, B. dan Ellison, L. (1992) School Development Planning. Harlow: Longman Group U.K. Ltd.

Depdiknas. 2007. Pembangunan Pendidikan Nasional 2005 - 2007. Departemen Pendidikan Nasional

Harris, B.M. 1990. Improving Staff Performance Through In-Service Education. Massachusetts: Allyn and Bacon Inc.

Marzano, dkk. 1993. Assesing Student Outcomes Performance Assessment Using the Dimensions of Leraning Model. United State: ASCD.

Peterson, C and Martin E.P. (2004) Character Strength and Virtues, Seligman, Oxford University Press.

Renstra Kementrian Pendidikan Nasional Tahun 2010-2014

Sara E. Thomas, S.E. (2006) Character Building from Inside Out. http://www.yale.edu/ ynhti/curriculum/units/2006/6/06.06.07.x.html

Surya, H.M. 1998. Peningkatan Profesionalisme Guru Menghadapi Pendidikan Abad ke-21n (I); Organisasi \& Profesi. Suara Guru No. 7/1998. Hlm. 1517.

Stiles, K.E. dan Loucks-Horsley, S. 1998. Professional Development Strategies: Professional Learning Experiences

UU. No. 14 Tahun 2005 tentang Guru dan Dosen

Undang-Undang Nomor 20 Tahun 2003 tentang Sistem Pendidikan Nasional 